\title{
Female Educational Ideals in the oeuvre of Stanisław Podoleński ${ }^{1}$
}

\section{Ideały wychowawcze kobiet w twórczości Stanisława Podoleńskiego}

\begin{abstract}
Reflection on educational ideals is inseparable from man's educational activity. While providing education, we must have a vision of knowledge, skills, features, and qualities, we would like our student to possess in the future. For the purpose of this paper, I have decided to present the concept of ideal of female education of the interwar period in the works of Stanisław Podoleński, based on a broad scope of female-related issues addressed in his articles and books. Executing a reconstruction may enable us to understand the specific character of women's education and schooling in the Poland of the interwar period and may constitute an element $\mathrm{z}$ allowing us to trace changes within the field of educational teleology which occurred in Poland in the 2oth and 21st century.
\end{abstract}

Keywords: ideal of education, ideal of female education, female education, interwar period, Stanisław Podoleński, Catholic education of women.

* Dominika Jagielska (ORCID: 000o-0003-4633-0550) - Ph.D., adjunct in Department of High School Pedagogy and the Polish Pedagogical Thought, Institute of Pedagogy, Jagiellonian University; e-mail: dominika.jagielska@uj.edu.pl.

1 The article was written as a result of a research project Ideaty wychowawcze kobiety w 2o-leciu międzywojennym - między tradycją a zmiana społeczną [Female Educational Ideals in the Interwar Period - Between the Tradition and the Social Change], financed from the DSc budget of the Faculty of Philosophy at the Jagiellonian University. 
Streszczenie: Refleksja dotycząca ideałów wychowawczych nieodłącznie wiąże się z działalnością wychowawczą człowieka. Wychowując następne pokolenia musimy przecież mieć przed oczyma jakieś wyobrażenie wiedzy, umiejętności, cech i właściwości, które chcielibyśmy, aby nasz wychowanek posiadał w przyszłości. W niniejszym artykule zdecydowałam się na ukazanie koncepcji ideału wychowawczego kobiety okresu międzywojennego w twórczości Stanisława Podoleńskiego, kierując się szeroko zakreślaną w jego artykułach i książkach problematyką kobiecą. Przeprowadzone rekonstrukcja może pozwolić na lepsze zrozumienie specyfiki wychowania i kształcenia kobiet w Polsce w okresie międzywojennym, a także może stanowić jeden z elementów umożliwiających prześledzenie zmian w zakresie teleologii edukacyjnej w Polsce w XX i XXI wieku.

Słowa kluczowe: ideał wychowania, ideał wychowania kobiety, wychowanie kobiet, okres międzywojenny, Stanisław Podoleński, katolickie wychowanie kobiety.

\section{Introduction}

Deflection on educational ideals is inseparable from man's educational activ1 ity. While providing education to subsequent generations, we must have a vision of knowledge, skills, features, and qualities, we would like our student to possess in the future. Therefore, the matter is important to both practical and theoretical aspects of pedagogy. Hence, considerations on the essence of an educational ideal and its historical and contemporary examples have always been addressed by such sub-field of pedagogy as educational philosophy, general pedagogy, or theory of education.

In the Polish pedagogy, theoretical studies on the problem of educational ideals were widespread both in the interwar period and the soviet domination until 1989 and in contemporary times. However, works from before 1939 have been forgotten by pedagogues to a large extent- most likely for historical and ideological reasons. ${ }^{2}$ Only after 1989 has a tendency to return to the rich and

2 Since 1944-1945, soviet communists had been gradually taken over the liberated lands and ensured their political hegemony in Poland through international treaties. The communist ideology, due to its character, had no interest, neither cognitive nor practical, in continuing and developing the pedagogical thinking of the interwar period, which was characterized, to a large extent, by national and Christian (Catholic) approach. To the contrary, any support or reference to these ideas was, 
diversified reflections of educational theorists and practitioners of the interwar period occurred and the long-forgotten interesting and well-developed pedagogical concepts - including the ones referring to educational ideals - were brought back to light.

Among scholars who reflected upon the phenomenon (with regard to both formal, theoretical, and practical aspects) in the interwar period, there were: Jan Ciemniewski, ${ }^{3}$ Ignacy Chrzanowski, ${ }^{4}$ Sławomir Czerwiński, ${ }^{5}$ Michał Klepacz, ${ }^{6}$ Stanisław Łempicki, ${ }^{7}$ Wincenty Granat, ${ }^{8}$ Andrzej Niesiołowski, ${ }^{9}$ Michał Sopoćko, ${ }^{10}$ Lucjan Zarzecki. ${ }^{11}$ Despite the fact that there have been numerous

from the socialist perspective, undesired and dangerous to keep the 'people's government' in hold of power in Poland and, thus, such attempts were punished in various ways. Only 1989 and its subsequent political, economic, and social changes created opportunities for scholar to study and refer to the works of Polish pedagogues of 1918-1939 freely, as exemplified by the following works: J. Kostkiewicz, Kierunki $i$ koncepcje pedagogiki katolickiej w Polsce 1928-1939, Kraków 2013; A. Smołalski, Ideały wychowawcze w polskiej myśli pedagogicznej od XVI w. do końca II Rzeczypospolitej, Opole 1994; E. Bartkowiak, Formacje zakonne wobec problemu dzieci pozbawionych opieki w Polsce w latach 1918-1939, Zielona Góra 2009, p. 295; E. Kruszyńska, Dydaktyczny charakter powieści dla dziewcząt $w$ dwudziestoleciu międzywojennym, Torun 2009, p. 293, and numeorus others.

3 J. Ciemniewski, 'Kierunki organizacyjne i ideały wychowawcze we współczesnym szkolnictwie polskim', Muzeum, (1937) p.190-196; J.Ciemniewski, 'O nowym człowieku', Ruch Katolicki, (1936).

4 I. Chrzanowski, Polski ideał wychowawczy, in: I. Chrzanowski, Około wychowania narodowego. Trzy odczyty, Warszawa 1932.

5 S. Czerwiński, O nowy ideał wychowawczy, Warszawa 1934.

6 M. Klepacz, Kierunki organizacyjne i ideały wychowawcze we wspótczesnym szkolnictwie polskim, Katowice 1937.

7 S. Łempicki, Polski ideał wychowawczy, Lwów, Warszawa 1938.

8 W. Granat, 'Katolicki ideał wychowawczy', Miesięcznik Katolicki i Wychowawczy, 8, 9, 10, (1936).

9 A. Niesiołowski, 'O istocie, genezie i funkcji ideałów', Kultura i Wychowanie, 5 (1938). This concept was discussed in: D. Jagielska, J. Kostkiewicz, Pedagogika humanizmu społecznego Andrzeja Niesiołowskiego, Kraków 2015.

10 M. Sopoćko, Polskie i katolickie ideaty i systemy wychowawcze, in: Katolicka myśl wychowawcza. Pamiętnik II Studium Katolickiego w Wilnie w dn. 28.VIII-1.IX.1926, (ed.)

S. Bross, Poznań 1937.

11 L. Zarzecki, O idei naczelnej polskiego wychowania, Warszawa-Poznań 1919. 
studies on the educational ideal from the theoretical perspective and analyses of its examples in the interwar period conducted back in the time and contemporarily, they did not address the problem of the female educational ideal. Polish textbooks on the history of education present some concepts on education of women, but these are, in most cases, secondary themes and refer to the periods before the beginning of the 2oth century. ${ }^{12}$ Contemporary studies on female educational ideals in Poland are sparse. Elements of such an analysis may be found in works by: Elwira Kryńska, Agnieszka Szarkowska, and Urszula Wróblewska, ${ }^{13}$ and Wiesław Jamrożek and Dorota Żołądź-Strzelczyk, ${ }^{14}$ which presented selected concepts of female education and role models, as well as practices relating to female education. However, it seems that numerous concepts have remained unacknowledged or forgotten, although they show how the woman was perceived in the interwar period. For the purpose of this paper, I have decided to present the concept of ideal of female education of the interwar period in the works of Stanisław Podoleński, ${ }^{15}$ based on a broad scope of female-related issues addressed in his articles and books.

12 Compare Historia wychowania, vol. 1, (ed.) Ł. Kurdybacha, Warszawa 1965, vol. 2, Warszawa 1967; Historia wychowania: wiek XX, vol. 1-2, (ed.) J. Miąso, Warszawa 1981; S. Kot, Historia wychowania, vol. 1-2, Warszawa 1994.

13 Ideały wychowania $i$ wzory osobowe narodu polskiego w XIX i XX wieku, (ed.) E. J. Kryńska, Białystok 2006; Kobieta a patriotyzm. Konteksty historyczno-pedagogiczne XVI-XX wieku, (ed.) E. J. Kryńska, A. Szarkowska, U. Wróblewska, Białystok 2012.

14 Rola i miejsce kobiet w edukacji i kulturze polskiej, vol. 1, (ed.) W. Jamrożek, D. ŻołądźStrzelczyk, Poznań 1998; W. Jamrożek, D. Żołądź-Strzelczyk, Studia z dziejów edukacji kobiet na ziemiach polskich, Poznań 2001.

15 Stanisław Tadeusz Podoleński was a Polish Jesuit, social writer, teacher, and educator. He was born in 1887 to a clerk family. In 1905, he joined the Jesuit order, he studies philosophy and theology. In 1915 we was ordained a priest in Kraków. He belonged to a group of Jesuit writers and contributors to Przegląd Powszechny. He published 13 books and booklets, c. 200 articles in various periodicals. His works emphasise the claims of catholic social teachings in building moral values and education. Upon arrest in 1939, he was detained in Auschwitz and Dachau concentration camps. He died in the latter one in 1945. See L. Grzebień, Podoleński, Stanisław Tadeusz, in: Internetowy Polski Słownik Biograficzny, http://www.ipsb.nina.gov.pl/a/ biografia/stanislaw-tadeusz-podolenski, accessed: 12.07.2017. 


\section{The notion of an educational ideal}

Reflection upon education ideals shall Begin with a short presentation of the notion, which serves as the basic variable for analysis of Stanisław Podoleński's texts. Contemporary authors who have been writing on the subject of educational ideals include: Antoni Smołalski, ${ }^{16}$ Heliodor Muszyński, ${ }^{17}$ Feliks Araszkiewicz, ${ }^{18}$ Stanisław Nalaskowski, ${ }^{19}$ Elwira J. Kryńska. ${ }^{20}$ Definitions of the phenomenon proposed by individual theorists bear significant resemblance.

Attempts to explain the notion of educational ideal most often refer to the goals of education. For example, Antoni Smołalski defines the term as: 'basic spiritual (moral, above all), material, and organizational values, which are the most valued and desired by a given community ..., a vision of an optimum human being, the best social order, and the most favourable natural environment, within such a scope that can be shaped by man.'. ${ }^{21} \mathrm{He}$, thus, points to historical and social circumstances in which educational ideals function. A similar definition is proposed by Andrzej Nalaskowski, who defines the term in question as a 'synthesis of teaching and educational goals and their related values.'22 On the other hand, Wincenty Okon perceives it as a 'complete set of goals and other norms that regulate educational activity', ${ }^{23}$ while Heliodor Muszyński emphasizes that an education ideal comprises of various kinds of desired attitude and spiritual value sets. ${ }^{24}$

As we may see, individual definitions of the educational ideal treat the phenomenon as a certain set or synthesis of individual education goals defined by values, attitudes, personality traits, competences, skills, and knowledge - desired and

16 A. Smołalski, Ideały wychowawcze.

17 H. Muszyński, Ideał i cele wychowania, Warszawa 1974.

18 F. Araszkiewicz, Ideały wychowawcze Drugiej Rzeczypospolitej, Warszawa 1978.

19 S. Nalaskowski, O ideale wychowania i celach kształcenia. Studium z pedagogiki porównawczej, Toruń 1993.

20 E. J. Kryńska, Ideały wychowania.

21 A. Smołalski, Ideały wychowawcze, p. 7.

22 S. Nalaskowski, O ideale wychowania, p. 9.

23 W. Okoń, Słownik pedagogiczny, Warszawa 1981, p. 101.

24 H. Muszyński, Ideał, p. 296-297. 
preferred at a given time and place, that is within a given historical moment and a given society. If we assume this manner of defining of the phenomenon under study, we must emphasize the fact that each country exhibits different educational ideals in various moments of its historical development. Therefore, the interwar period in Poland will be characterized by ideals specific to this period.

The definitions of an educational ideal presented above seem to be describing the analysed motion thoroughly enough, however, it seems that, for the purpose of historical study, it is equally important that we take into consideration a perspective of the phenomenon under study in the period analysed. Because my corpus comprises of Podoleński's works form the years 1918-1939, it is crucial to discuss the definition of an educational ideal that functioned during the interwar period and which might have been referred to by the author in his writings. An extensive theoretical study on educational ideals can be found in Andrzej Niesiołowski's works. He considers and educational ideal to be: 'a separate and objectified feature (or a system of features) of a substrate category or activity, by a subject (individual or a group), as perfect'. ${ }^{25}$ With such an understanding of an ideal, it always belongs to somebody: a group or an individual, it is thus conditioned socially. Apart from that, an ideal is abstract and unattainable by definition, yet, striving towards it seems to be a natural trait of every personality. What is more, Niesiołowski differentiates between an education ideal and a personality model - he understands the latter one as a specific object or subject of imitation, execution, to a large extent, of a feature or features of an educational by an object of a person. ${ }^{26} \mathrm{~A}$ similar distinction between an educational ideal and a personality model is used nowadays as well - the former is perceived as a general, abstract construct, while the latter is a specific rendition of the ideal, features considered worth to be followed, made real in something or somebody. A personality model understood this way is rather a means of education which provides the student with a tangible example of execution of characteristics contained in an educational ideal. ${ }^{27}$

25 A. Niesiołowski, $O$ istocie, genezie, p. 288.

26 Ibid., p. 286-30o. A more detailed study of the theoretical concept of an educational ideal in relations to political and social ideologies may be found in: D. Jagielska, J. Kostkiewicz, Pedagogika humanizmu.

27 See E. J. Kryńska, Ideał wychowania a wzór osobowy. Niektóre typy uznawanych wzorów osobowych w XIX i XX wieku, in: Ideaty wychowania, p. 23-32. 
Therefore, Niesiołowski treats and educational ideal as a set of certain characteristics of a man, which are considered to be perfect by a given community or by a given social group in a given time and place.

Thus, as we can see, the interwar and the current perspective on the described phenomenon correspond with one another greatly. They may be taken as a basis for the purpose of extraction of threads of education ideals during a qualitative analysis of the texts' content. In this paper, I shall focus on female educational ideals in works by Stanisław Podoleński - a representative and voice of a large portion of Polish society in the interwar period.

\section{Catholic anthropology as the basis of female educational ideals in the oeuvre of Stanisław Podoleński}

First of all, while discussing educational ideals in works by Stanisław Podoleński, we need to emphasize the basic premise of his outlook on education, including education of women. As a priest and friar (Jesuit), he formed his beliefs based on basic premises of Catholic social science and its derivative anthropology. These are also the foundations of the female educational ideals he formed for his times.

Man is God's greatest creation and was created as the woman and the man. Men and women are, according to Podoleński, one's another equals as humans, but they differ both physically and psychically. ${ }^{28}$ He sees these differences mostly in such aspects as smaller physical abilities, less resistance to physical effort, more sensitive emotionality, related to more intense emotional experiences, a livelier imagination, female intuition. He also attributes the woman with such natural characteristics as attaching greater importance to emotional reasons and inconsistent disposition. The female nature may result in common vices if the fair sex: superficiality, verbosity, passion for external things (clothing, appearance), lack of objectivity, premature judgement, excessive sensitivity, emotional instability, but it entangles, in a particular manner, such virtues as: kindness, persistence, ability to make sacrifices, religiousness, empathy. ${ }^{29}$ Therefore, she differs from the man greatly.

28 Compare S. Podoleński, U progu. Książka dla młodych, Kraków 1938, p. 102-103;

S. Podoleński, Rozwód a zdrowie narodu, Kraków 1926, p. 139.

29 S. Podoleński, Rozwód, p. 138-141; S. Podoleński, Podręcznik Pedagogiczny. Wskazówki dla rodziców i wychowawców, Kraków 1921, p. 148. 
As Podoleński emphasises, the woman's physical weakness results in her substantial dependency on another person - the man. Judged from the perspective of this feature, in various societies, the woman is perceived as creature inferior to the man and her equality with representatives of the male sex is not recognized. According to Podoleński, the phenomenon is affected not by culture, but by religion (its essence and status within society) and the society's moral level - the lower it is, the worst situation of women. ${ }^{30}$ As he explains, 'only Christianity elevated the woman, it gave her spiritual greatness and showed her respect', ${ }^{31}$ because only in Christianity the woman is perceived in the same way as the man - as 'likeliness and the image of God, a creature given an immortal soul, designated, by supernatural order, to possess God eternally'. ${ }^{32}$ While recognizing the equality of the woman and the man with regard to their essence and the aim of their existence, Podoleński points to such differences between the two sexes that determine their different social roles and tasks and, thus, to differences in their education and definition of their educational goals and ideals.

These differences are significant enough to be taken into consideration in an educational process. In Podoleński's way of thinking, this means that the basic educational goals apply both to boys and girls, but due to differences between the male and the female nature, some of them should be modified educations should reflect these dissimilarities. ${ }^{33}$ Therefore, he believes coeducation is an unsuitable organisational model of an educational system in general, in particular with regard to the adolescent age. ${ }^{34}$ He claims that proper education should advance and strengthen positive sides of each person and suppress and eradicate the negative ones. Since each sex is characterised by their distinctive virtues and vices, there is a need for different educational modes - taking the female and the male nature into consideration. According to Podoleński, in the case of women, particular educational goals should include: 'maintaining internal balance and developing self-control and resistance to external influ-

30 S. Podoleński, Rozwód, p. 138-141.

31 Ibid., p. 144.

32 Ibid., p. 141.

33 S. Podoleński, Podręcznik Pedagogiczny, p. 147.

34 Ibid., p. 145. 
ence, to which the woman is especially vulnerable. ${ }^{35}$ This means that female and male educational ideals must differ as well.

\title{
Female educational ideals in the oeuvre of Stanisław Podoleński
}

Therefore, taking the above-discussed vision of the woman as a baseline, in a number of his books, booklets, and articles, Podoleński reflects upon various problems related to the way women function in society, problems faced in his contemporary times, combines themes of building Christian morals, educational issues, and the welfare of the Polish nation. Taking into consideration the number of texts on female issues he authored, we might say that they were especially important to him. Based on his works, some female educational ideals may be defined as they are shown directly or indirectly in his philosophical and educational treaties. These ideals found in the analysed works are permeated with the approach exhibited by Catholic social science.

One of the most basic and important female educational ideals depicted in Podoleński's works is the female ideal of a wife. for Podoleński, this is the basic role of the woman, closely related to the second most important educational ideal in his opinion - that of a mother. The woman is especially predestined to play these to social roles due to her biological and psychological properties, while proper execution of these roles is, for Podoleński, the best way the woman may fulfil her tasks on earth and the most proper path to eternal life. ${ }^{36}$ Additionally, marriage is one of the sacraments blessed by Jesus Christ.

Podoleński emphasises that marriage, as a life path, was sanctified from the perspective of religion:

\begin{abstract}
unmarried status, maidenhood, was not enobled. It may be, in some cases, respected, as long as it is an act of sacrifice or renunciation in favour of service to a great ideal, but it is superior to marital status only, if it is motivated by a wish to commit oneself to God exclusively, to devote one's hear and life to $\mathrm{Him}^{37}$
\end{abstract}

35 Ibid., p. 149.

36 See: S. Podoleński, 'O poszanowanie kobiety', Przegląd Powszechny, 181 (1929), p. 344.

37 S. Podoleński, $U$ progu, p. 103-104. 
Therefore, another female educational ideal appears here as an alternative for marriage - the ideal of a convent life - but it is neither well developed nor promoted in Podoleński's oeuvre as a whole.

Summing up, Podoleński perceives marriage as the most important way of life, for the woman in particular, therefore one must be well-prepared to undertake this task - with the help of education ${ }^{38}$ oriented on execution of the educational ideal of a good wife. What are the desired traits of the woman playing such a special role? Podoleński points to the fact that education for marriage should cover both man and women. It is not a way of preparing people for marriage directly, but of 'shaping people who are capable of becoming good husbands and wives at a given time, because they have acquired the necessary virtues of the heart and will, they have learnt a healthy outlook on the matters of the sexes, to respect one another, and to respect the married status and marital duties.' ${ }^{39}$ Therefore the features of the educational ideal of a wife , form Podolenski's perspective, are based, first and foremost, on the knowledge of marital rights and duties and awareness of how important it is to fulfil them properly - based on true faith and knowledge on the importance of marriage assigned it by God. Preparation for marriage is similar for both women and men, it applies to shaping certain personal traits especially important to endurance of a sacramental union. These features form an educational ideal and include:

- willingness and ability to stay pure, based on knowledge on male-female relations and strong will; ${ }^{40}$

- love for the good and rejection of evil, related to resistance to external negative influence ${ }^{41}$ - which is especially important for women (I will elaborate on this later on);

- kindness and modesty based on the knowledge that dignity and beauty of each human lies within their own soul, therefore they may be judged based on their internal virtues only, not the external ones, ${ }^{42}$

- awareness of the importance of marriage, sanctity of this union and importance of duties resulting from the roles of a husband and wife, ${ }^{43}$

38 S. Podoleński, Rozwód, p. 230.

39 Ibid., p. 230-231.

40 S. Podoleński, Rozwód, p. 232; S. Podoleński, U progu, p. 78-80.

41 S. Podoleński, Rozwód, p. 232-235.

42 Ibid., p. 235-239; S. Podoleński, U progu, p. 83.

43 S. Podoleński, Rozwód, p. 241-242. 
- the virtue of temperance and self-control, also in male-female relations, connected to awareness of moral improperness of contraception and abortion. ${ }^{44}$

The most proper ways of achieving these personal traits are, according to Podoleński, both natural ones, such as: avoiding opportunity and exercising strong will, and supernatural ones - including faith, prayer, receiving holy sacraments. ${ }^{45}$ Therefore, he understands education of a person ready to be married as education of a highly moral human being. It is, therefore, closely connected to faith and religiousness - its arousal and development. He might have believed that developing morality will be much at least strongly impeded without religiousness.

Thus, an educational ideal of a wife is reflected in a woman, who is her husband's

companion, with whom he might be able to share his joys and sorrows, but one who could offer him honest help in all matters of life. He wants to find a person not only kind and loving, but also diligent, sensible, reliable, on whom he could lean in all situations. ${ }^{46}$

An ideal wife must be wise, responsible, practical, she should support her husband in overcoming all problems that every married couple may come across in their lives. What is more, Podoleński criticises numerous women inn his contemporary Times for too playful a lifestyle, carelessness, frivolity, interest in fashion and one's own appearance. He claims that a highly moral man will not wish to marry such a woman - she puts him a way with her spiritual deception which visible on the surface. ${ }^{47} \mathrm{He}$ points that

the woman, equal to the man as a human being and thus having her own value and a beautiful soul, who instead sacrifices it, or at least sets it aside, for care for her body and clothing - it is indeed a degradation of 'man'.48

This is where he identifies the reasons for reluctance of his contemporaries to marriage and puts the blame for this situation on education of girls, which moves away from the educational ideals of a wife and mother and promotes immorality and focusing on external values.

44 Ibid., p. 245-247.

45 S. Podoleński, U progu, p. 89-91.

46 S. Podoleński, 'Czy zmierzch kobiety?', Przegląd Powszechny, 168 (1925), p. 306.

47 Ibid., p. 306.

48 S. Podoleński, 'W sprawie niewłaściwej mody', Przegląd Powszechny, 163 (1924), p. 215. 
Therefore, Podoleński considers modesty and timidness to be the important constituents of a female educational ideal of a wife or a candidate for wife. He describes these features as a natural virtue which protects the woman against humiliation, ${ }^{49}$ which makes the men see her 'as a human, not a female'. ${ }^{50} \mathrm{He}$ emphasises that human sexual drive reacts with mechanical automation to external stimuli - therefore the need for taking care for oneself and avoiding exposure of oneself, and others, to problems related to controlling it. Modesty and timidity help others to stay good. ${ }^{51}$ Podoleński points out that

this duty is mutual, but it applies to the woman mostly, because her inherent passive, receptive character enables her to ignore these matters more easily, while the man, due to his more active, aggressive character, is prone to face more obstacles, because he his nature makes him react to external stimuli more strongly.... This is how a woman worth the name acts and has ever acted, she is modest, that is, she avoids in her existence all things that could exasperate the man. ${ }^{52}$

Therefore, Podoleński sees education a highly moral person as the most important aspect of education for marriage - this brings positive results both in the eternal and earthly life of every man. In marriage, by company of a highly moral person, one strengthens himself in goodness, experiences less temptations and more opportunities to build and maintain their morality - a marital relation with such a person refines you. ${ }^{53}$ For each person, the woman in particular,

spiritual beauty ... is the ultimate and the most important one. It is the source of the unmatched charm of femininity and innocence which glows on her forehead and fills the man with worship. ${ }^{54}$

The woman, from Podoleński's perspective, must gain the man's respect as she is weaker physically, but such a case is possible only due to her high spir-

49 Ibid., p. 217-218.

50 Ibid., p. 216.

51 S. Podoleński, 'O poziom moralności publicznej', Przegląd Powszechny, 176 (1927), p. 296-298.

52 Ibid., p. 296.

53 S. Podoleński, U progu, p. 81.

54 S. Podoleński, 'O poszanowanie kobiety', Przegląd Powszechny, 181 (1929), p. 338. 
itual value - this is her only guarantee of protection against humiliation and fall. ${ }^{55}$ According to Podoleński, modesty, timidness, obeying high moral standards ensures the woman is respected by the man and that equality of the sexes is executed in practice within a given marriage and within the entire society. A high moral level is especially important to the woman's relations with her husband. Podoleński writes:

whether she gets up swiftly in the morning to prepare everything her beloved husband needs on his way and then she waits and longs for him and greets him joyfully at the door to ensure the rest of his day is pleasant - or she wakes up and does her daily chores out of duty, tries to avoid unpleasant situations upon his return home and even feels relieved he leaved the house..$^{56}$

Therefore, one needs to be thoughtful in choosing their partner. The woman should be thus educated in such a way so that she would look for internal virtues of her future husband and not for his external beauty and - if necessary could fight temporary passions by her own reason, ${ }^{57}$ rejecting a candidate who represents a dubious moral level. The female ideal of a wife requires the woman to choose reason over passion, oppose her own desires in the name of fulfilling God's commandments and maintaining marital bliss.

Lack of sensibility in choosing ones partner may result in an unhappy union, which - from Podoleński's perspective - cannot be dissolved by divorce and must persevere (apart from very few cases in separation of the spouses should be declared, but never a dissolution of a union entered into before God). An educational ideal, according to Podoleński, attempts to fulfil their marital duties well despite difficulties, both external ones and those generated by their spouse. He notes that

the woman will rather bear her suffering heroically, but she will endure for a noble rule: 'Marital happiness may or may not be there, but obligations imposed by marriage must be fulfilled'. However, only can such a spiritual strength be found by a woman, who, supported by a powerful lever of faith,

55 S. Podoleński, 'Czy zmierzch kobiety?', p. 308-309.

56 S. Podoleński, U progu, p. 82.

57 Ibid., p. 104-127. 
looks upon the world from a higher viewpoint and will not fear to make any sacrifice if her task may be done. ${ }^{58}$

He accepts the possibility that not all women in all circumstances will be able to make such a sacrifice for eternal goodness: 'there are cases, however, in which the sacrifice of this sort exceeds all measures ... making it impossible to require all people to make it. ${ }^{\prime}{ }^{9}$

But even if such a case occurs, divorce is not a solution. Podoleński points out that:

the history and practice of the divorce law have proved that this is a seemingly saving solution, while it actually brings opposite results, because it favours an outburst of egoism and lowest instincts, ... it leads to a general decrease in morality and, along with it, brings back all relations of paganism, with its humiliation and contempt for the woman. ${ }^{60}$

In several of his articles, Podoleński puts a strong emphasis on the fact that divorce law (a possibility of executing divorce) and introduction of secular marriages act to the woman's disadvantage - they lower the general moral level in society and enable abuse of women on the pretext of giving them full cultural freedom. ${ }^{61}$ As we may see, the bar for the woman is set very high. While

58 S. Podoleński, 'Prawo rozwodowe a szczęście małżeńskie', Przegląd Powszechny, $145 / 146$ (1920), p. 125.

59 Ibid., p. 125.

60 S. Podoleński, Rozwód, p. 148.

61 See S. Podoleński, 'Nemezis rozwodu', Przegląd Powszechny, 161 (1924), p. 193-207; S. Podoleński, 'Małżeństwo wobec Kościoła i państwa', Przegląd Powszechny, 147/148 (1920), p. 229; S. Podoleński, 'Prawo rozwodowe a szczęście małżeńskie', Przegląd Powszechny, 141/142 (1919), 420-431; S. Podoleński, 'Prawo rozwodowe a szczęście małżeńskie', Przegląd Powszechny, 143/144 (1919), p. 111-126; S. Podoleński, 'Prawo rozwodowe a szczęście małżeńskie', Przegląd Powszechny, 143/144 (1919), p. 403415; S. Podoleński, 'Prawo rozwodowe a szczęście małżeńskie', Przegląd Powszechny, 145/146 (1920), p. 120-134; S. Podoleński, 'Prawo rozwodowe a szczęście małżeńskie', Przegląd Powszechny, 145/146 (1920), p. 200-211; S. Podoleński, 'W sprawie kodyfikacji prawa małżeńskiego w Polsce', Przegląd Powszechny, 169, 1926, p. 148-163; S. Podoleński, 'W kwestji nowego prawa małżeńskiego w Polsce', Przegląd Powsze- 
creating such an image of an educational ideal of a wife, Podoleński seems to bear in mind the effort which enables its execution.

The female education ideal of a wife in Podoleński's works is complemented by the ideal of a mother. The author believes that becoming a mother and playing this social role is connected in a special way to the woman's nature. He builds a certain educational ideal of a mother for which education of every woman should strive - it is closely connected to the woman's ideal of a wife. We may assume that a woman who is close to meeting all ideal feature of a wife will also be close to the characteristics of a mother which Podoleński considers to be the most proper ones.

Podoleński describes the educational ideal of a mother through motherly love, which constitutes a voluntary sacrifice, free from egoism, symbolizes devotion and submission to God's will. ${ }^{62}$ According to him, the mother is 'a personification of love and devotion, who taught him [a child - D. J.] to make his first steps in life, warned him and instructed him, led him to God and was the first, before any priest, to etch God's rules into his heart'.63 And for this selfless love and devotion, related to the role of a mother, girls must be prepared. It is possible only through proper moral education - because only a high moral level, in connection with faith, piety, and religiousness, may ensure the woman endures in her role of a mother and fulfils it in a proper manner.

Although motherly and fatherly love is enrooted in human nature - as Podoleński notes, 'longing for a child lies within the deepest nooks and crannies of human soul' ${ }^{\prime 64}$ - the role of education for the role of a mother cannot be underestimated, not only because of the well-being of children, but also a general well-being of women. As Podoleński writes:

in every period of history, with mathematical precision, whenever morality collapsed, so was the woman ridden roughshod. Therefore, it has always

chny, 174 (1927), p. 186-206; S. Podoleński, 'Dlaczego chcą nam narzucić rozwody?', Przegląd Powszechny, 190 (1931), p. 57-70; S. Podoleński, 'Dlaczego chcą nam narzucić rozwody?', Przegląd Powszechny, 190 (1931), p. 184-205.

62 S. Podoleński, U progu, p. 72-73

63 S. Podoleński, 'Czy zmierzch kobiety?', p. 310.

64 S. Podoleński, U progu, p. 72. 
been in the woman's best interest to maintain a high cultural level of society and to prevent any signs of moral looseness. ${ }^{65}$

Care for this moral level of society is executed the most efficiently through education of children. If it is so, the role of a mother becomes the most important function in society and, as such, requires preparation - both moral and substantive.

The educational ideal of a mother and wife is also connected - in accordance to the Church's social teachings - rejection of both contraception and abortion. Podoleński describes them from numerous perspectives, pointing to medical, social, and legal consequences, but he considers the ethical issued to be the most important ones. On the basis of Catholic teachings of the Church and arguments $\mathrm{f}$ some medical doctors of the time, he points to the fact that a human foetus us a human from the moment of inception, although he still is immature and developing. Thus abortion is a homicide and no man should agree to it, especially no Catholic. ${ }^{66}$ Therefore, the female educational ideal of a mother also includes awareness of immorality of execution of such birth control forms and allowing their legal execution on social level.

However, according to Podoleński, playing the role of a mother as well as possible does not mean w woman must be confined at home and focused on care for her husband, children, and house only. A woman who wants to be a good mother should go outside, be an active participant in improvement or correction of her children's educational environment in its broad meaning. Such an action, bold and diligent, putting pressure on the state and the closest social environment, taken up individually or jointly in various women's organisations, is expression of maternal love. ${ }^{67}$ Therefore, the educational ideal of a mother encompasses the woman's social activity. Acting towards improvement in the surrounding reality is one of the elements of the educational ideal

65 S. Podoleński, 'Czy zmierzch kobiety?', p. 313.

66 See S. Podoleński, O życie nienarodzonych, Kraków 1933; S. Podoleński, 'O życie nienarodzonych', Przegląd Powszechny, 196 (1932), p. 161-176; S. Podoleński, 'O życie nienarodzonych', Przegląd Powszechny, 196 (1932), p. 301-324; S. Podoleński, 'W walce z poczęciem życia', Przegląd Powszechny, 205 (1935), p. 3-23; S. Podoleński, 'O życie nienarodzonych', Przegląd Powszechny, 197 (1933), p. 147-163; S. Podoleński, 'Jeszcze w sprawie życia „nienarodzonych"', Przegląd Powszechny, 202 (1934), p. 25.

67 S. Podoleński, 'Czy zmierzch kobiety?', p. 317-318. 
of a mother. Passiveness, interest in the most immediate household circle only, seems to be an undesired attitude. The educational ideal refers to an active woman, a social worker - according to a principle that a better society creates better environment for education and development of a person.

Although, as exhibited in Stanisław Podoleński's works, the basic female educational ideal are the ideal of a wife and mother, it does not necessarily mean that he does not take other goals of girls' education beyond these fundamental ones into consideration. On of this ideal's elements is the issue of proper schooling adjusted to the woman's aptitude and capabilities that will provide her, if necessary, with a source of income. Although he believes that the woman ideally should not be forced to work hard outside home, ${ }^{68}$ but - as it seems - it is not equal to a lack of such opportunity. The author considers proper vocational education adjusted to girl's capabilities, aptitude, and motivation to be a perfect solution, which secures not only the woman, but also - in difficult situations - her children as well. As he writes, women:

must receive such education, so that each and every one of them is able to provide for herself without the support of others, If she marries, this may be helpful, or at least there will be no harm in it; if her fate decides otherwise, she will be able to lead an independent life and her future will be secured. The old method of general" education must thus be given up and girls, upon graduation from elementary schools, shall be sent to high schools, from which they could go on to universities or to trade, industrial, and other vocational schools. ${ }^{69}$

According to Podoleński, proper education does not collide with preparation of women for their roles as good wives and mothers. However, he calls for resignation of general education, which puts emphasis on arts and foreign languages, and a shift towards vocational education, which will ensure a profitable profession in the case of non-standard life circumstances. ${ }^{70}$ Such an education will, however, be, from the perspective of the author under study, needed to fulfil the woman's basic needs only, should she stay unmarried. Nevertheless, such

68 S. Podoleński, Rodzina w Sowietach, Kraków 1938, p. 7.

69 S. Podoleński, Podręcznik Pedagogiczny, p. 151-152.

70 Ibid., p. 152. 
an approach seem to be step forward in the process of building an ideal image of the woman, accepted by the Church, in Polish society of the interwar period.

\section{Conclusions}

Stanisław Podoleński's philosophical and educational works focused mostly on women and the way they functioned within society of his time, as well as on education, problems, and hazards women may come across. By and by, these reflections enable us to reconstruct female educational ideals lying at the base of this priest and academician pedagogical beliefs. Based on the Church's social teachings, Podoleński shows extended and closely interrelated ideals of the woman as a wife and mother of a high moral level, who execute their basic tasks resulting from female nature within the Catholic perspective with humility and modesty. In contemporary times, they will most likely be perceived as very traditional, nevertheless, they are a creation of their times and the existing Polish society in which they functioned. Yet, emphasis on the active role of women in society and the necessity to provide women with proper education seem to go beyond the framework of a traditional outlook on the role of the woman in society and, perhaps, will serve as an introduction to more contemporary takes on the female educational ideal. As we may see, the ideals pointed to by Podoleński exhibit high complementarity and accentuate, first and foremost, the role of moral education, which still constitutes an important field of education.

Executing a reconstruction may enable us to understand the specific character of women's education and schooling in the Poland of the interwar period and may constitute an element $\mathrm{z}$ allowing us to trace changes within the field of educational teleology which occurred in Poland in the 2oth and 21st century. However, the problems of educational ideals of Polish women in the years 19181939 present in works of educators and social activists of that time still requires further studies.

\section{Literature}

Araszkiewicz F., Ideały wychowawcze Drugiej Rzeczypospolitej, Warszawa 1978.

Bartkowiak E., Formacje zakonne wobec problemu dzieci pozbawionych opieki w Polsce w latach 1918-1939, Zielona Góra 2009. 
Chrzanowski I., Polski ideał wychowawczy, in: I. Chrzanowski, Około wychowania narodowego. Trzy odczyty, Warszawa 1932.

Ciemniewski J., 'Kierunki organizacyjne i ideały wychowawcze we współczesnym szkolnictwie polskim', Muzeum, (1937) pp.190-196.

Ciemniewski J., 'O nowym człowieku', Ruch Katolicki, (1936).

Czerwiński S., O nowy ideał wychowawczy, Warszawa 1934.

Granat W., 'Katolicki ideał wychowawczy', Miesięcznik Katolicki i Wychowawczy, 8, 9, 10, (1936).

Grzebień L., Podoleński, Stanisław Tadeusz, in: Internetowy Polski Słownik Biograficzny, http://www.ipsb.nina.gov.pl/a/biografia/stanislaw-tadeusz-podolenski ${ }_{2}$ accessed: 12.07.2017.

Historia wychowania, vol. I, (ed.) Ł. Kurdybacha, Warszawa 1965, Vol. 2, Warszawa 1967.

Historia wychowania: wiek XX, Vol. I, II, (ed.) J. Miąso, Warszawa 1981.

Ideaty wychowania i wzory osobowe narodu polskiego w XIX i XX wieku, (ed.) E. J. Kryńska, Białystok: 2006.

Jagielska D., J. Kostkiewicz, Pedagogika humanizmu społecznego Andrzeja Niesiołowskiego, Kraków 2015.

Jamrożek W., D. Żołądź-Strzelczyk, Studia z dziejów edukacji kobiet na ziemiach polskich, Poznań 2001.

Klepacz M., Kierunki organizacyjne i ideały wychowawcze we współczesnym szkolnictwie polskim, Katowice 1937.

Kobieta a patriotyzm. Konteksty historyczno-pedagogiczne XVI-XX wieku, (ed.) E. J. Kryńska, A. Szarkowska, U. Wróblewska, Białystok 2012.

Kostkiewicz J., Kierunki i koncepcje pedagogiki katolickiej w Polsce 1928-1939, Kraków 2013.

Kot S., Historia wychowania, Vol. 1, 2, Warszawa 1994.

Kruszyńska E., Dydaktyczny charakter powieści dla dziewcząt w dwudziestoleciu międzywojennym, Toruń 2009.

Kryńska E. J., Ideał wychowania a wzór osobowy. Niektóre typy uznawanych wzorów osobowych $w$ XIX $i \mathrm{XX}$ wieku, in: Ideały wychowania i wzory osobowe narodu polskiego w XIX i XX wieku, (ed.) E. J. Kryńska, Białystok: 2006, pp. 23-32.

Łempicki S., Polski ideał wychowawczy, Lwów, Warszawa 1938.

Muszyński H., Ideał i cele wychowania, Warszawa 1974.

Nalaskowski S., O ideale wychowania i celach kształcenia. Studium z pedagogiki porównawczej, Toruń 1993.

Niesiołowski A., 'O istocie, genezie i funkcji ideałów', Kultura i Wychowanie, 5 (1938), pp. 286-303.

Okoń W., Słownik pedagogiczny, Warszawa 1981.

Podoleński S., U progu. Książka dla młodych, Kraków 1938.

Podoleński S., 'Czy zmierzch kobiety?', Przegląd Powszechny, 168 (1925), pp. 305-318. 
Podoleński S., 'Dlaczego chcą nam narzucić rozwody?', Przegląd Powszechny, 190 (1931), pp. $57-70$.

Podoleński S., 'Dlaczego chcą nam narzucić rozwody?', Przegląd Powszechny, 190 (1931), pp. 184-205.

Podoleński S., 'Jeszcze w sprawie życia „nienarodzonych”, Przegląd Powszechny, 202 (1934), pp. 25-32.

Podoleński S., 'Małżeństwo wobec Kościoła i państwa', Przegląd Powszechny, 147/148 (1920), pp. 229-238.

Podoleński S., 'Nemezis rozwodu', Przegląd Powszechny, 161 (1924), pp. 193-207.

Podoleński S., 'O poszanowanie kobiety', Przegląd Powszechny, 181 (1929), pp. 333-348.

Podoleński S., 'O poziom moralności publicznej', Przegląd Powszechny, 176 (1927), pp. 286-308.

Podoleński S., 'O życie nienarodzonych', Przegląd Powszechny, 196 (1932), pp. 161176, 301-324.

Podoleński S., O życie nienarodzonych, Kraków 1933.

Podoleński S., 'O życie nienarodzonych', Przegląd Powszechny, 197 (1933), pp. 147-163.

Podoleński S., Podręcznik Pedagogiczny. Wskazówki dla rodziców i wychowawców, Kraków 1921.

Podoleński S., 'Prawo rozwodowe a szczęście małżeńskie', Przegląd Powszechny, 145/146 (1920), pp. 120-134, 200-211.

Podoleński S., 'Prawo rozwodowe a szczęście małżeńskie', Przegląd Powszechny, 141/142 (1919), pp. 420-431.

Podoleński S., 'Prawo rozwodowe a szczęście małżeńskie', Przegląd Powszechny, 143/144 (1919), p. 111-126, pp. 403-415.

Podoleński S., Rodzina w Sowietach, Kraków 1938.

Podoleński S., Rozwód a zdrowie narodu, Kraków 1926.

Podoleński S., 'W kwestji nowego prawa małżeńskiego w Polsce', Przegląd Powszechny, 174 (1927), pp. 186-206.

Podoleński S., 'W sprawie kodyfikacji prawa małżeńskiego w Polsce', Przegląd Powszechny, 169 (1926) pp. 148-163.

Podoleński S., 'W sprawie niewłaściwej mody', Przegląd Powszechny, 163 (1924), pp. 208-226.

Podoleński S., 'W walce z poczęciem życia', Przegląd Powszechny, 205 (1935), pp. 3-23.

Rola i miejsce kobiet w edukacji i kulturze polskiej, Vol. 1, (ed.) W. Jamrożek, D. Żołądź-Strzelczyk, Poznań 1998.

Smołalski A., Ideały wychowawcze w polskiej myśli pedagogicznej od XVI w. do końca II Rzeczypospolitej, Opole 1994.

Sopoćko M., Polskie i katolickie ideały i systemy wychowawcze, in: Katolicka myśl wychowawcza. Pamiętnik II Studium Katolickiego w Wilnie w dn. 28.VIII-1.IX.1926, (ed.) S. Bross, Poznań: 1937.

Zarzecki L., O idei naczelnej polskiego wychowania, Warszawa - Poznań 1919. 